\title{
THE FORMULATION IMPACT OF INVESTMENT-HAMPERING REGIONAL REGULATIONS INVESTMENT
}

\author{
Ray Ferza, Moh. Ilham A Hamudy, M S Rifki. \\ Research and Development Agency (BPP) of the Ministry of Home Affairs \\ JI. Kramat Raya No. 132 - Senen, Jakarta \\ Telephone; 082111393927 \\ ilhamhamudy80@gmail.com
}

Article Received on: 2019-01-16; Revised on: 2019-03-11;

Accepted on: 2019-04-05.

DOI : http://dx.doi.org/10.30641/kebijakan.2019.V13.229-244

\begin{abstract}
After the ruling of the Constitutional Court (MK), Ministry of HomeAffairs (MoHA) and the Provincial Government can no longer revoke the problematic Regional Regulation (Perda) via an executive review. This situation, would increase the difficulty for MoHA to revise the investment-hampering regional regulations. The problematic Regulations includes of Karawang District's Perda No.1 of 2011 on the Management of Man Power and Bandung City's Perda No. 19 of 2012 on Disturbance Permit and Charges. Therefore, this study seeks to have a general understanding of the two regulations, the factors that influence the formulation, and to establish a guideline for the formulation of an ideal regional regulation. To achieve those objectives, this research used the descriptive qualitative method. The results of the study reveal that the formulation of regional regulation process is plagued by problems such as the absence of Academic Papers, the insufficient stakeholders' involvements, the lack of monitoring by the provincial government on the district/municipal regulation formulation process, lack of understanding of investment principles and confusion with the regional government control function. The various factors that cause the issuance of problematic regulations are, among others, the central government's regulatory packages, sociological elements, political elements, multi-interpretation in understanding the central government's regulation, as well as the fiscal capacity of the region. Therefore, the guidance of the Ministry of Home Affairs in supervising the regional government during the formulation process of districts/ municipal regulation related to investment is very much needed.
\end{abstract}

Keywords: formulation; perda; regional regulation investment; regional government. 


\section{INTRODUCTION}

\section{Background}

This Study is conducted to review the formulation process of the investmenthampering regional regulations, hereinafter referred to as Peraturan Daerah (Perda). The Perdas are those considered to substantially impede the entry of investment to a region. The regulations observed in this Study are Karawang District's Perda No. 1 of 2011 on the Management of Man Power and Bandung City's Perda No. 19 of 2012 on Disturbance Permit and Charges. The two are selected since they are substantially in the opposite of the investment principles, and that they are also nominated to be revoked. Karawang District Perda No. 1 of 2011 on the Provision of Manpower is considered to violate the principle of free internal trade ${ }^{1}$, a principle simply understood as commodity distribution activities from production to consumption within one state jurisdiction. One of its benefits were to control the relationship between labours and their superiors. ${ }^{2}$ one of the provisions in the Perda is to limit the allocation of local and non-local labour. This violates the principle of investment, where it should fulfill the criteria of justice as coined several other criteria as appropriateness, legal relevance, pro-incentive, efficient, ideal competition, proper conflict management, and institutional correctness. ${ }^{3}$ Perda No. 1 of 2011 is not yet officially revoked, but it is declared to be revoked by the Governor of West Java Province. While Perda No. 19 of 2012, was revoked due to complicated arrangement of the disturbance permit and that it ignores the criteria of the disturbance permit in MoHA

1 KPPOD, "Regulasi Usaha Di Daerah: Kajian Perda Pungutan Dan Perizinan," 2017, 5.

2 Leo Agustino, "Otonomi Daerah Dan Perdagangan Internal Bebas Di Indonesia," Jurnal Ekonomi dan Pembangunan (JEP) XII (2004): 1-35.

3 KPPOD, "Regulasi Usaha Di Daerah: Kajian Perda Pungutan Dan Perizinan.”
Regulation No. 27 of 2009 on the Guidance of Disturbance Permit issued three years earlier.

As an illustration, the national investment achievements are considered to be fairly good. The Ease of Doing Business (EoDB) rating has been moving positively in the last four years. This achievement must be continuously improved by the government. According to Bank Indonesia, the economic policy package, through the deregulation in the central government level, has supported the achievement of investment in the national level. The growth of national investment supported by the regulatory policy in the form of the Central Government Policy Package should be supported by the growth of regional investment through the issuance of regional regulation as mandated by regional autonomy within the framework of the Unitary State of the Republic of Indonesia. ${ }^{4}$ However, based on the study by the Regional Autonomy Implementation Monitoring Committee (KPPOD), despite that there are several Provincial Government having good Perda, there are 14 Provincial Governments having below average quality regulations in terms of investment.

MoHA with the Law No. 23 Of 2014 on Regional Government is in a strategic position to revamp the investment climate in the region. Article 249-252 of Law No. 23 of 2014 has paved the way for the deregulation process of provincial's and district's/city's investment regulations. The investmenthampering regulation can be regarded as distortions to the economic improvement of the local communities. So far, the spirit to deregulate investment policy in the local level has been performed by the Ministry of Home Affairs (MoHA), the latest is the follow-up of dictum no. 8 of Presidential Instruction No. 1

$4 \quad$ Sondakh, "Fungsi Local Investment Regulation Dalam Meningkatkan Keunggulan Daerah Pada Pertumbuhan Investasi," Jurnal IImu Hukum AMANNA GAPPA 21 (2013). 
of 2016 on the Acceleration of the National Strategic Projects Implementation. The MoHA responded it by issuing the Instruction of the Minister of Home Affairs No. 582/476/ SJ on the Revocation of Regional Regulation (Perda), Regulation of the Head of Region (Perkada) and Decision of the Head of Region that Inhibits Bureaucracy and Investment Permit. In order to support the policy, The MoHA empowered it by issuing the Instruction of the Minister of Home Affairs No. 582/100/ SJ which derivated from Article 148 Minister Regulation No. 80 of 2015.

As the result, 3143 regulations are deregulated and thousands of them are Regulations from District/City Government. ${ }^{5}$ The formulation process of Perda might be seen as a regional legislation process. ${ }^{6}$ For example, quotes Juridisch Woordenboek wetgeving or the legislation process can be understood as the process of formulating legislation both at the central and regional levels. However, based on existing law, such as Law No. 23 of 2014 on Regional Government, the term legislation is no longer applicable in the regional governance processes. Law No. 23 of 2014 adopts the term 'formulation process of legal product', to replace the term 'legislation process'. With the understanding that within the state administration of the Republic of Indonesia. The regional representative body formally known as the Regional People's Legislative Assembly (DPRD), together with the regional government is recognized as the of regional governance which are under the power of the President. Although at a certain point the DPRD also has a regulatory function at

5 Tim UJDIH BPK Perwakilan Provinsi Jawa Barat, "Mekanisme Pencabutan / Pembatalan Peraturan Daerah, Peraturan Kepala Daerah, Dan Keputusan Kepala Daerah Yang Bermasalah Berdasarkan Peraturan Perundang-Undangan Di Indonesia," 2016. 5-15

6 P Siahaan, Politik Hukum Pembentukan UU Pasca Amandemen UUD 1945 (Jakarta: Konstitusi Press (KONPress), 2012). the regional level that is similar to the central legislative body. This redefinition can also be seen from the institutional perspective in the series of regional formulation processes such as the redefinition of the Regional Legislation Program (Prolegda) into the Program for the Formulation of Regional Regulation (Propemperda) and the Regional Legislation Body in DPRD is redefined into the Regional Regulation Formulation Body (Bapemperda).

Referring to Kemendagri.go.id web page, the number of Perda/Perkada being revoked in relation to Regional Tax, Regional Charges, License and Permits (Disturbance permit, Business License, and others) is $62 \%$ or more than half of all regional regulations being revoked.

The deregulation of the investment sector by the MoHA is currently coming to a halt because the MoHA's authority to deregulate was annulled by the Constitutional Court (MK) with two Decisions. First, Decision of the Constitutional Court No. 137/PUU-XII/2015 which stated that the deregulation authority of MoHA and the provincial government on regional legal products are limited to provincial regulations (for MoHA), Governor Regulations (for MoHA) and District Head'l Mayor's Regulations. A regional regulation issued by District/City Government can no longer be able to be deregulated via the executive review process. Second, the Constitutional Court's decision on the judicial review No. 56/PUU-XIV/2016 which ended the MoHA deregulation authority over all the Regional Regulations, be it District/City or Province.

After the two decisions, the authority of MoHA and the provincial government in overseeing the District/City Regulations and Provincial Regulations practically only exist in the prevention stage, thereby compounding the importance of strengthening the monitoring of the regional regulation formulation process. As such, the issuance of regional regulation 
which acts as a barrier to investment may be prevented. This is also one of the key recommendations of the Constitutional Court Judges' considerations, which stated that to create a better governance, the government needs to increase the supervision of regional regulations in the state of prevention through executive preview to the draft of regional regulations (no longer in the realm of repression through executive review). ${ }^{7}$ Not only on the supervision issue, in order to improve the formulation process the local governance needs to address the issue of public participation. ${ }^{8}$ The importance of public participation on formulation process were also explored by T.M. Saragih. ${ }^{9}$ On his studies, public participation can not be neglected and should be considered as important in the process of spatial planning local regulation.

Studies on investment or regulations governing regional investment have been done before. On regional investment, Sopandi and Mazmulmunir, for example, examine regional regulations in the context of the development of regional investment climate. In their study, they offer a way of developing investment objects such as the availability of industrial zones, integrated economic development zones, and other areas. Sopandi also analyses the possible risks, some of them are related to some problematic regulations such as Article 10 of the Manpower Law and Law No. 5 of $1999 .{ }^{10}$ In addition to Sopandi, Sondakh also examines regional regulations

7 M Nur Sholikin, "Penghapusan Kewenangan Pemerintah Untuk Membatalkan PERDA; Momentum Mengefektifkan Pengawasan Preventif Dan Pelaksanaan Hak Uji Materil MA," Rechtsvinding (2017): 1-6.

8 Sunarso Danusastro, "Penyusunan Program Legislasi Daerah Yang Partisipatif," Jurnal Konstitusi 9, no. 4 (2012): 643-660.

9 Tomy M Saragih, "Konsep Partisipasi Masyarakat Dalam Pembentukan Peraturan Daerah Rencana Detail Tata Ruang Dan Kawasan," Jurnal Sasi 17, no. 3 (2011): 11-20.

10 N Sopandi, Andi \& Nazmulmunir, "Pengembangan Iklim Investasi Daerah," Kybernan 3, no. 1 (2012): 10-24. from another point of view, their usefulness in the investment climate. Sondakh, for example, said the emergence of problematic regional regulations that damage the investment climate is an indication of the sub-optimal function of regional regulations to strengthen local and regional competitiveness. He also considers the model of local investment regulation to be implemented is still not responsive to the market and it tends to slow down the rate of investment growth in the region. ${ }^{11}$ The last study conducted by the KPPOD (2017) examines the problematic regulations based on the economic principles. The KPPOD only examines the content of problematic regional regulations. ${ }^{12}$

This study is, of course, different from the previous three studies. Sopandi and Mazmulmunir review local regulations on the development of investment objects and Sondakh review the regional regulations from the point of view of the usefulness of local regulations in improving the investment climate in a region. This study is aimed to complete the study conducted by the above three studies including KPPOD. While KPPOD only examines the content of various regional regulations such as Cilegon, Tangerang, and others, this study will examine two regional regulations, Karawang District's Perda No.1 of 2011 and Bandung City Perda No.19 of 2012, from the process of its formulation. Related studies of the regional regulation process have also been done by with a generic-empirical study which resulted in a policy brief. This study will examine the formulation process of regional regulations

11 Sondakh, "Fungsi Local Investment Regulation Dalam Meningkatkan Keunggulan Daerah Pada Pertumbuhan Investasi."

12 M. Y Prawira, Tata Kelola Ekonomi Daerah:Survei Pemeringkatan 32 Ibukota Provinsi Di Indonesia (Jakarta, 2017). 
which are considered to harm the investment climate. ${ }^{13}$

\section{Formulation of the problem}

Issues related to the formulation process of regional regulations are selected because they are the actual problems of the home affairs governance. In the era of competition between countries, the government's capacity in shaping investment supportive regulations becomes very important. MoHA or the Provincial Government need to optimize the preventive supervision function in the formulation of the regional regulation. The formulation process that occurred before the issuance of Investment-hampering Regional Regulations something that needs to be observed in depth, although there are other issues arising from the Constitutional Court's Decision, not only on the formulation process of regional regulations. Other issues, such as the capacity of the Supreme Court (MA) as the only authority to overturn the Regional Regulation, are also interesting to be an alternative topic for subsequent studies.

\section{Research Objectives}

On this occasion, by using the regional regulation formulation process as the scope, this study might be used as a scientific reference for policies related to preventive control for Investment-hampering regional regulations. Thus, this study will focus on problem-solving of the issue, among others, a general description of the formulation process of investment-hampering regional regulations, the factors that have a role in the process, as well as guidelines for the establishment of an ideal regulation after the Constitutional Court's decision.

13 S Solikin, M.N \& Butt, Policy Briefs Pembuatan Peraturan Di Parlemen Daerah (DPRD) (Jakarta, 2009).

\section{Method}

This study is a case study uses the analytical method within the qualitative approach. The qualitative approach demonstrates a different approach to scientific study. The area of the study is West Java (Bandung and Karawang). Both places were chosen because the regulation in the two regions is currently a public discourse. The regional governments are required to facilitate investment, this contrasts with the two regulations in Karawang and Bandung which have negative economic impacts and complicate licensing, thus hampering the investment climate.

Data collection techniques were conducted by identifying several problematic regulations, then two regional regulations, namely Karawang District's Perda No.1 of 2011 on the Management of Man Power and Bandung City Perda No. 19 of 2012 on the Permit and Charges, are selected. Data collection was then performed by visiting several related institutions as well as documenting, collecting secondary data, and conducting in-depth interviews directly with several resource persons from regional government, community groups, labour organizations, and communities in both cities. Data collection also performed through discussion forums and meetings with expert speakers. After that, the data was analysed and written in the form of the study report.

\section{DISCUSSION}

\section{InternationalinstitutionssuchasPrinciples}

for Responsible Investment recommended some basic points that policymakers must do in formulating investment-related regulations, among others: formulation of regulations must be based on empirical evidence of regional investment developments, with measurable achievements in the formulation of regulations related to the financial system; 
investment-related regulations should be based on role of the various parties in the business world, including their role in sustainable economy; strengthening policy design; the regulation must contain an easy to understand stipulations. ${ }^{14}$

In this section we will describe some of the issues mentioned in the introduction section, such as the general description of the investment-hampering regional regulation formulation process, the factors have a role in the process and the establishment of guidelines for the formulation of an ideal regulation after the Constitutional Court's decision.

\section{An overview of the formulation impact of Investment-hampering Regional Regula- tions}

In general, the formulation process of a regional regulation is a process set up with rigid laws and regulations. The formulation process of regulation may be seen as a process of establishing a foundation for buildings, which generally have the same principle but will have some specific provisions in accordance with the purpose of the building. The laws and regulations applicable to the regulation formulation process of a regional regulation are generally applicable to all regional regulations.

\section{Karawang District's Perda No 1 of 2011}

The industrial relations between government, workers, and employers must be kept in a balance. ${ }^{15}$ In the case of the formulation process of Perda No.1 of 2011, the regional government tends to support the workers or laborers. In addition, in the hierarchy of legislation, the issue of Perda No. 1 Of 2011 can also be viewed from the

14 PRI; Heath; A., Paty; M., \& Martindale, Global Guide to Responsible Investment Regulation, 2013, https://www.unpri.org/download?ac=325.

$15 \mathrm{~T}$ Yulianto, "Hukum Sebagai Sarana Untuk Melindungi Pekerja/Buruh Dalam Hubungan Industrial.," Orbith 8 (2012): 104-108. juridical side where Law No. 13 of 2003 on Manpower has adopted the principle of free internal trade and rejected the discrimination in labour recruitment, however the Regional Regulation of Manpower in the Province of West Java, such as the one in Karawang District is not in line with the principles promoted by Law No. 13 of 2003.

During the formulation process of the Perda, the Karawang district government admitted that the government acknowledges the principle of the Law No. 13 of 2013, but the sociological and political situation strongly influence the formulation of the draft regional regulations (Raperda) and its issuance. As such, the content of Perda No. 1 of 2011 is not in accordance with the general criteria of investment-related regulations, which is justice. The supporting Laws for Karawang District's Perda No. 1 of 2011 are Law No. 10 of 2004 on the Establishment of Laws and Regulations, Law No. 32 of 2004 on Regional Government and MoHA Regulation No. 16 of 2006 on Guidelines for the Formulation of Regulations Produced by Regional Governments.

The problems in the formulation process of Regulation No. 1 of 2011 is mainly not in technical term. The underlying problems in conflict with the investment principles are the sociological and political elements. The sociological influences in this regional regulation are very pronounced. The transition of Karawang District from an agrarian area to an industrial area encourages the Karawang District Government to form a policy that affects the need for the regional communities in a regional regulation. This encourages Karawang District to form a problematic regulation which is against the investment principles, such as the obligation to have $60 \%: 40 \%$ allocation for the local workers. Although there is no formal technical problem, the impact of the Law No. 10 of 2004, Law No. 32 of 2004, and MoHA Regulation No. 16 
of 2006 which has not encouraged the public participation and the Academic Paper is quite strong. The involvement of the stakeholders is relatively minimal even though they clearly should have the interest and will become the users of the regulations.

APINDO, for example, claimed to be involved only at the final stage of the formulation process for Karawang District's Perda No. 1 of 2011, and it was only for the formalities ${ }^{16}$. Although, the community might be able to actively participate in the formulation process of the regional regulation. APINDO, as one of the major social organizations for the investors, have a very minimal involvement in the formulation process, when it should be crucial for a healthy the industrial relations in the Karawang District. ${ }^{17}$

The findings show that the political influence in the formulation of the regional regulation is quite strong. Perda No. 1 of 2011 was formed around the time where the General Election of Regional Head was about to be held. As the result, the Regional Regulations initiated by the DPRD is leaning toward the popular issues in the local community and disregarding the vision of investment principles. The transactional politics by the local community through the Labour Union of Karawang District push forward the "affirmative action" to be adopted in the Perda No.1 of $2011 .{ }^{18}$ The Labour Union often stage intensive demonstrations as the form of resistance, including when the Regional Government is conducting a meeting with APINDO during the formulation process of the regulation. ${ }^{19}$

The problem between the users of the

16 BPP Kemendagri, "Proses Pembentukan Peraturan Daerah Yang Menghambat Investasi" (Jakarta, 2017).

17 E Zuhro, R. S \& Prasojo, Kisruh Peraturan Daerah: Mengurai Masalah Dan Solusinya (Yogyakarta: Ombak, 2010). p50

18 Based on the interviews with Excecutive Director of APINDO Karawang, Mr. Pujianto

19

lbid
Perda No. 1 of 2011, the Trade Union, and APINDO became unresolved when APINDO and the Labour Union conflicting aspirations are not mediated by the District Government. ${ }^{20}$ APINDO and the Labour Union have never met in an official forum to collaboratively formulate manpower regulations for Karawang District. In the context of Perda No. 1 of 2011, the industrial relation is not in a balanced position.

\section{The Role of the Provincial Government}

West Java Province Government as one of the supervisory parties also cannot do much during the formulation of Perda No. 1 of 2011. Since the role of provincial government supervision and the role of the Governor to stop the local workforce allocation on Perda No. 1 of 2011 is not supported by the law and regulation, then the provincial government have no choice but to pass the problematic issue. West Java provincial government assures that the law No. 23 of 2014 and MoHA Regulation No. 80 of 2015 which govern the Province authority, would enable the provincial government to be more powerful in the preventive measures during the formulation process of District/City regulations. ${ }^{21}$ As such, issuance of regional regulations with conflicting terms with the principle of investment may be minimized.

3. Bandung City Regulation No. 19 of 2012

The supporting Laws for the Bandung City's Perda No. 19 of 2012 are Law No. 12 of 2011 on the Establishment of Laws and Regulations, Law No. 32 of 2004 on Regional Government, and MoHA Regulation No. 53 of 2011 on Guidelines for the Formulation of Regulations Produced by Regional Governments. The technical problems during the formulation process are not too significant. This regulation is even supported by the Academic Paper, something that is

20 Ibid

21 Based on the interviews with Head of Sub Division of Regulations at Legal Bureau of West Java Secretariate, Mr. Aam Amzad. 
often lacking in other regional regulations formulation process, even though it is stipulated in the prevailing laws and regulation.

The background problems in this Regulation, such as re-registration charges, is the interpretation of the Bandung City Government of the Law No. 28 of 2009 and MoHA Regulation No. 27 of 2009. Bandung City Government interpreted that the law No. 28 of 2009 allows the city government to apply re-registration charges for the Disturbance Permit. This Regulation is amended by Regional Regulation No. 7 of 2016 after a clarification by the Legal Bureau in 2013 on the re-registration charges which was considered to be in conflict with the MoHA Regulation No 27 of 2009. In this instance, the Bandung City Government and the Central Government had different interpretations.

Regarding the compounding requirements, the regional regulation formulation parties view it as the control mechanism for the permit issuance process. A good control is achieved when the applicant (the entrepreneur) can provide the complete documents as required. This provision is then revised and simplified through a Mayor Regulation. ${ }^{22}$ Another problematic issue is the absence of compensation. The parties responsible for the formulation of the regional regulation stated that this absence shows that there is a limitation on the capacity of the region to introduce the incentive system to nurture a good investment climate. ${ }^{23}$ The compensation is interpreted by the Regional Government as something that is not an obligation to be provided by the regional government but a discretionary matter.

In accordance with the provisions of the law and regulations, the regional regulation was reviewed by the Directorate General of

\footnotetext{
22 Based on the interviews with Head of Legal Division of Bandung Municipal, Mr. Bambang Suhaya.

Regional Financial Management of MoHA and the Provincial Government, but the problematic issues such as re-registration charges, compounded requirements, and the absence of compensation remain, even after the executive preview. This is because the evaluation process in the preview doesn't use the investment principle parameter.

4. The role of the Provincial Government and the relevant Ministries/Institutions

For the record, the formulation process of Regional Charges Regulation is one of those that need an evaluation form the Government and/or relevant Ministries/ Institutions (K/L). Perda No. 19 of 2012 on Disturbance Permit and Charges of Bandung City is one of those. This Regulation was evaluated at the provincial level and the $\mathrm{K} / \mathrm{L}$ level, the Provincial Government let the regulation through in the Ranperda despite being unfriendly to investment because they think it was in line with the control function of the regional government. The Ministry of Finance (MoF) itself did not use the principle of Easiness to Do Business when evaluating the regional regulation. It only reviews in terms of compliance with Law No. 28 of 2009 on Regional Taxes and Charges.

\section{Relevant Factors in the Formulation Process of Investment-Hampering Regula- tions.}

As discussed in the previous sections, it is clear that the driving factors in the formulation of Regulation No. 1 of 2011 of Karawang District on the Provision of Manpower which discourages investment in are as follows:

\section{Sociological Factors}

The unique characteristic of the need in a particular region causes bias on the formulation process of the regional regulation, which leans toward an affirmative action as a response to the short-term need of the region, ignoring the investment principles related to its long-term need. In Karawang District, 
the typology transition between agrarian to industrial society plays an important role in shaping the conduct of the regional regulation formulation parties. The DPRD members are motivated to draft a very affirmative manpower policy for the local community in the short term and ignoring that it potentially hampers investment in the long term. The parties formulating the regional regulations are ignoring the investment principles and the ease of investing which has a long-term perspective.

\section{Political Factors}

Transactional politics has become the major factor in the formulation process of Perda No. 1 of 2011. This statement is also in line with a study conducted by Thalhah, which stated that the political aspect is highly visible on the issue of democratization. ${ }^{24}$ Similarly, in this case, the industrial relations that do not side with the business gave birth to a regional regulation that inhibits investment. Trade Union, with the local community as its members, is much more politically benefited. Their intensity to interact with the regional regulation formulator are also higher than those of the investor.

The Participation Aspect implies that the formulation of the Perda only using the labour's perspective, without considering the other parties in the industrial relations. Entrepreneurs are important elements to be involved in the formulation process. The Stakeholders of the Regional Regulation No.1 of 2011 do not have an equal proportion in the formulation process.

\section{Regulation Factor}

The laws and regulations at the Central Government level that doesn't support the establishment of a pro-investment regional regulation also become one of the factors. The principle of regulating investment-related

24 M. Thalhah, "Peraturan Daerah Bermasala," Jurnal IImu Sosial, 30(65) (2007): 231-237. regulations requires a strong commitment from the policymakers such as the acknowledgment of the role of industrial relations actors. The policymakers formulate regulations relating to the business world based on evidence of investment development. ${ }^{25}$ These things can only be realized through the existence of academic papers with empirical studies.

When Perda No. 1 of 2011 was formulated, there was no clear elaboration in the Central Government regulation regarding the need of academic papers and the role of the provincial government in overseeing the formulation process of a Regional Regulation, as such although the provincial government realized that there are errors, without the existence of such regulation at the Central level, the Provincial Government does not have the power to stop the issues that discourage investment to be included in the regional regulation.

In Bandung City Perda No. 19 of 2012 on Disturbance Permit and Charges, the factors influencing the formulation of the problematic regulation are:

\section{Interpretation and Regulation Factors}

There are multiple interpretations in the government that encourages the formulation of the issues which are against the investment principle. Several issues such as Re-registration Charges and Compounding Requirements are built into the Regional Regulation due to the different interpretation between the Regional Government and the Central Government regarding the Law No. 28 of 2009 and MoHA Regulation No. 27 of 2009. The Regional Government interpret that the Law No. 28 of 2009 allows a chargeable re-registration and compounding requirements and that they are also allowed as part of their control mechanism. But in the end, MoHA clarify and cancelled the Perda

$\overline{25}$ PRI; Heath; A., Paty; M., \& Martindale, Global Guide to Responsible Investment Regulation. 
by Decision Letter (SK) No. 188.34.5303 of June 17, 2016, stating that the re-registration charges are contrary to Article 15 of MoHA Regulation No. 27 of 2009. But the role of $\mathrm{MoHA}$ in this instance is only on the ReRegistration Charges, as for the compounding requirements for the disturbance permit, it was the City Government of Bandung who simplifies of the implementing rules in the form of a Mayor Regulations.

2. The View of the Regional Government toward the Control Mechanism

The Provincial Government or City Government considers that in order to perform the control function on the corporate world, the regional government reserves the right to have compounding permits. Their view is that the requirements for the disturbance permit which has more items than recommended in the MoHA Regulation No. 27 of 2009 are part of the control mechanism by the Regional Government to the business world. This provision is contrary to the principle of investment because it is not creating ease in doing. ${ }^{26}$ However, in its formulation process, both the Provincial Government and the Ministry of Finance did not prevent it to be included in the Regional Regulation.

3. The Region's Fiscal Capacity Factor

The Region's Fiscal Capacity plays a role in how the region would be able to present the incentive and disincentive systems for the Ease of Doing Business. ${ }^{27}$ Bandung City Perda No. 19 of 2012 does not have the provision of compensation to the applicant when the applicant receives a level of service

26 A. N. Suparman, H. N., Rheza, B., Agustine, T. E., Prawira, M. Y., Febryanti, N. A., \& Jannah, Regulasi Usaha Di Daerah Kajian Perda Pungutan Dan Perizinan, 2017.

27 Carr, J. B., Gerber, E. R., \& Lupher, E. W "Explaining Horizontal and Vertical Cooperation on Public Services in Michigan: The Role of Local Fiscal Capacity. Working Group on Interlocal Services Cooperation." (Michigan: Wayne State Universit, 2007), http://digitalcommons.wayne. edu/interlocal_coop/34. below the minimum level regulated in the MoHA Regulation No. 27 of 2009. The City Government considers that the compensation is not an obligation, the region may choose to provide it depending on its financial capacity. As a result, this issue was not submitted to be one of the provisions, either in Draft Regulation or the Final Regulation.

\section{The Ideal Formulation of Regional Regula- tion Post Constitutional Court Decision}

After the two Constitutional Court's decisions, the Ministry of Home Affairs can no longer revoke the regional regulations, either in the provincial or district/city level. It is certainly an utmost importance for the Ministry of Home Affairs to optimize its supervision during the formulation process of the regional regulation, considering the only 'ammunition' the Ministry has in guarding the regional regulation is in the preventive stage, not repressive stage, the preview activity not the review activity. Separately, in a limited discussion group held of the Ministry of Home Affairs' Research and Development on July $20^{\text {th }}, 2017$, has proposed various planned steps related to strengthening the MoHA's supervisory role in the formulation process of Regional Regulation. Along with temporary measures that will be submitted by the Directorate of Regional Regulation Products. Such as strict selection in registration number, reviving the mechanism of sanctions (report cards) for the formulation process of problematic regulation, as well as optimization of E-Perda.

Previously, international institutions Principles for Responsible Investment recommended some basic points that policymakers, must do in formulating investment-related regulations. Among others: formulation of regulations must be based on empirical evidence of regional investment developments, with measurable achievements in the formulation of regulations related to the financial system. Investment- 
related regulations should be based on role of the various parties in the business world, including their role in sustainable economy; strengthening policy design; the regulation must contain an easy to understand stipulations. ${ }^{28}$

At the national level, KPPOD proposed the specific and general criteria for investmentfriendly regulations. The general criteria are conformity to need, good substance, fairness, openness, fair competition, business incentives, efficiency and good conflict management. The specific criteria are LowCost Economy, Ease of licensing, and Capital or incentives. ${ }^{29}$

The Directorate of Regional Legal Products of MoHA planned various steps, such as a strict process for the registration number, strengthen the mechanism of sanction up to the evaluation stage of Regional Government Implementation Report (LPPD) for the Regional government which still formulating a conflicting regional regulation, and optimization of e-Perda. However, referring to the findings of the study, there might still be some room for improvement to produce an ideal guide for the formulation of regional regulations.

The findings of the study show, that there are other problems. One of them is no Academic Paper in the formulation of a Ranperda, although the central level, through Law No. 12 of 2011 and MoHA regulation No. 80 of 2015 where the Academic Paper is a must for a Draft of Regional Regulation. The problem with the absence of the Academic Paper in Perda No.1 of 2011 of Karawang District due to the lack of regulation that governs it. Although procedurally the question is answered, the strengthening of Academic

28 PRI; Heath; A., Paty; M., \& Martindale, Global Guide to Responsible Investment Regulation.

29 Suparman, H. N., Rheza, B., Agustine, T. E., Prawira, M. Y., Febryanti, N. A., \& Jannah, Regulasi Usaha Di Daerah Kajian Perda Pungutan Dan Perizinan.
Paper and the reinforcement of supervision for the existence of Academic Papers in the formulation of an Investment Regulation also must be resolved. The existence of Academic Paper is very important for regulations related to the investment climate. The investment climate requires measures based on empirical background, as well as the ability to have Regulatory Impact Assessment as the scientific basis for the Investment Climate Regulations. Academic Paper is believed to be a representative scientific study that can reflect that matter. ${ }^{30}$

The involvement of an expert team in the Academic Paper need to be improved. ${ }^{31} \mathrm{MoHA}$ Regulation No. 80 of 2015 only regulate the need of Academic Paper, the involvement of expert teams or academics is not mandatory. However, the mandatory involvement of an expert team should also consider the location of the regional area.

The next problem, such as the unavailability of industrial relations in the formulation of the regional regulations related to investment, need to be answered by a mechanism that protects all parties involved. In the principles of good regulatory process, the involvement of all parties or stakeholders is part of the dignity of legislation. ${ }^{32} \mathrm{MoHA}$ Regulation No. 80 of 2015 Article 26 has stipulated the involvement of community organizations. In the implementation stage at the regional level there are still irregularities, such as APINDO Karawang district as an organization that protects the community of entrepreneurs was less involved in the

$30 \quad$ A Basyir, "Pentingnya Naskah Akademik Dalam Pembentukan Peraturan Perundang-Undangan Untuk Mewujudkan Hukum Aspiratif Dan Responsif.," Kajian Hukum Dan Keadilan 2, no. 5 (2014): 285-306.

31 M Yani, "Penyusunan Naskah Akademik Sesuai Ketentuan Undang-Undang Nomor 12 Tahun 2011 Dalam Proses Pembentukan Peraturan Daerah," Jurnal Ilmu Hukum Maret, 5(1) (2014): 155-172.

32 J Waldron, J., \& Wamron, "The Dignity of Legislation," L. Rev 633, no. 2 (1995). 
process of formulation, and Bandung City Government has its own preference, such as KADIN which has more involvement in the process of establishing the City regulations related to the business world.

The next problem is that the provincial government supervision is less assertive because there is no regulation that underpins the commitment of provincial governments to crack down on the draft Perda. MoHA Regulation No. 80 of 2015 has anticipates such supervision problem and stipulate a registration number. However, business preview process of Ranperda still leaves issues such as the length of time of the issuance of the registration number which exceeds the stipulation in the legislation and the different of views on investment principles between various levels of government led to formulation of investment-hampering regulation.

The next problem is the different interpretation of regulations between the regional government (both city and province) and the central government, such the Law No. 28 of 2009 and MoHA regulation No. 27 of 2009 in addressing the disturbance permit. The central government considers that the heavy requirements may hamper investment but regional governments assume that this is a form of control. That is also the situation with the Re-registration of Disturbance Permit and Charges. Another issue is the Interpretation of disturbance permit which assumes the Hinder Ordonantie Law is still in effect, as such the Central Government cannot issue MoHA Regulation No. 19 of 2017 to revoke the disturbance permit but at the Central Government Level, the Hinder Orodonantie Law must be subject to the principle of Lex Posteriori derogate legi priori.

Other Issue, some sources say, in the principle of investment to have an incentive system for entrepreneurs, such as compensation for a level of service below the minimum level in the MoHA regulation. Where currently the City Government of Bandung mostly ignores. Because the City Government considered the compensation as a discretionary matter, with a consideration of the fiscal capacity of each region.

For those reasons, there is a need for an ideal guideline to formulate the regional regulations which support Investment.

First, Optimizing the information system to respond to all the findings. The e-Perda needs to be strengthened in terms of business processes, accessibility to all parties, involvement of all levels of government, the stakeholders, the Provincial Government and $\mathrm{K} / \mathrm{L}$ evaluators as one of the administrators for the Evaluation. The e-Perda existence also needs to be disseminated as widely as possible. Currently, the West Java Provincial Legal Bureau does not have the full understanding of the e-Perda business process. The Provincial Government think that the system is established as a system built in the Documentation and Information Legal Network (JDIH) portal. While in fact, the two systems have different functions. The e-Perda system may refer to the Brazilian e-Democracia system as a benchmark to develop an effective and efficient open legislative process. The portal that was first established by Brazilian Government in 2007. Every citizen is given an ID to log in to the portal and in real time may hold hearings. This portal also emphasizes the position of the regulation formulators as a crowd-sourcing facilitator. ${ }^{33}$

Second, some notes to strengthened the MoHA regulation No. 8 of 2015 are: The Academic Papers preparation need to be reinforced in the substance since this is the

33 C. F. S. De Faria, The Open Parliament in the Age of the Internet. (Edicoes Camara, 2013). 
base in determining the legal provisions ${ }^{34}$, the paper may include a historical side of the development of the investment climate in the area. ${ }^{35}$ It also needs to take into account the topology of the region, the capability of the region and its access to the academic institution. MoHA Regulation No. 80 of 2015 need to include a stronger rule in the process of forming the regional regulation, especially in terms of timeline and the consequences of delays in the formulation process undertaken by the Regional Government. For the JDIH system, the Academic Papers and the Draft of Regulation should also be published, to give the chance for the public to be involved in discussion during the formulation process. MoHA Regulation No. 80 of 2015 also need to push the obligation to involve the expert team and to involve the Vertical Institution during the review process in the Bapemperda $\mathrm{DPRD}$, in the way that the review process in the Legal Bureau of the Regional Government also involves the Vertical Institution.

Third, there is need of a parameter approved by a national consensus on matters deemed to support investment. In 2012 the MoHA and the Ministry of Law and Human Rights develop Joint Minister Regulation on the Human Rights parameters in the formulation of Regulations Produced by Regional Government.

\section{CONCLUSION}

\section{Conclusion}

Currently, the Regional Regulation formulation process is using an inappropriate mechanism. As previous studies and the observations of researchers, prove it. An example is a difficult time to perform facilitation process. Notice to the head of

34 Yani, "Penyusunan Naskah Akademik Sesuai Ketentuan Undang-Undang Nomor 12 Tahun 2011 Dalam Proses Pembentukan Peraturan Daerah." 35 regions and DPRD to revise the Draft of Regional Regulation to conform with the facilitation result also not strong enough to ensure compliance. To minimize the future problem with the regional regulations, MoHA should be firm, by not issuing a registration number for the draft and by submitting a judicial review to the Constitutional Court to revoke the Regional Regulation if the result of the facilitation, consultation, or evaluation has not complied within the time frame. In this way, the role of MoHA as the executive reviewer of the Provincial Government and Governor for the District/City would be optimized. As the consequence that MoHA can no longer revoke a Provincial Regulation, and the Governor can no longer revoke the District/City Regulation, there is a need to re-formulate the appropriate supervision and monitoring system of the regional government regulation products.

\section{Suggestion}

To say the least, there are three items that need to be re-formulate, which are, the strengthening of the Formulation of Regional Regulation Program (Prompemperda) mechanism, The strengthening of the Facilitation Mechanism for Draft of Regional Regulation (Perda) and Draft of Regional Head Regulation (Perkada), and the strengthening of the issuance mechanism for the registration number of Draft Regional Regulation (Ranperda) as one of the monitoring instrument (facilitation and evaluation) of the Draft of Provincial and District/City Regulation, before it is issued by the Regional Head. To support the progressive national policy coordinated by the Coordinator Minister of Economics, MoHA may issue a joint regulation with other Ministries on investment supportive parameters in the formulation of regional government regulation products to ensure that the Ease of Doing Business policy may be implemented nation-wide. Hopefully, there will be no more hesitance across the 
regional governments on issues related to investment climate.

\section{ACKNOWLEDGMENT}

We would like to thank the Centre for Regional Financial and Development for Research and Development Agency (BPP) of the Ministry of Home Affairs which has funded this research and also to the Bandung City Government, the Karawang Regency Government, the Indonesian Entrepreneurs Alliance (APINDO), and all who are involved in this research.

\section{REFERENCES}

Agustino, Leo. "Otonomi Daerah Dan Perdagangan Internal Bebas Di Indonesia." Jurnal Ekonomi dan Pembangunan (JEP) XII (2004): 1-35.

Basyir, A. "Pentingnya Naskah Akademik Dalam Pembentukan Peraturan Perundang-Undangan Untuk Mewujudkan Hukum Aspiratif Dan Responsif." Kajian Hukum Dan Keadilan 2, no. 5 (2014): 285-306.

Carr, J. B., Gerber, E. R., \& Lupher, E. W. "Explaining Horizontal and Vertical Cooperation on Public Services in Michigan: The Role of Local Fiscal Capacity. Working Group on Interlocal Services Cooperation." Michigan: Wayne State Universit, 2007.

Danusastro, Sunarso. "Penyusunan Program Legislasi Daerah Yang Partisipatif." Jurnal Konstitusi 9, no. 4 (2012): 643660.

Faria, C. F. S. De. The Open Parliament in the Age of the Internet. Edicoes Camara, 2013.

Kemendagri, BPP. "Proses Pembentukan Peraturan Daerah Yang Menghambat Investasi," 2017.

KPPOD. "Regulasi Usaha Di Daerah: Kajian Perda Pungutan Dan Perizinan," 2017.

Prawira, M. Y. Tata Kelola Ekonomi Daerah:Survei Pemeringkatan 32 Ibukota Provinsi Di Indonesia. Jakarta, 2017.

PRI; Heath; A., Paty; M., \& Martindale, W. Global Guide to Responsible Investment Regulation, 2013.

Saragih, Tomy M. "Konsep Partisipasi Masyarakat Dalam Pembentukan Peraturan Daerah Rencana Detail Tata Ruang Dan Kawasan." Jurnal Sasi 17, no. 3 (2011): 11-20. 
Sholikin, M Nur. "Penghapusan Kewenangan Pemerintah Untuk Membatalkan PERDA; Momentum Mengefektifkan Pengawasan Preventif Dan Pelaksanaan Hak Uji Materil MA." Rechtsvinding (2017): 1-6.

Siahaan, P. Politik Hukum Pembentukan UU Pasca Amandemen UUD 1945. Jakarta: Konstitusi Press (KONPress), 2012.

Solikin, M.N \& Butt, S. Policy Briefs Pembuatan Peraturan Di Parlemen Daerah (DPRD). Jakarta, 2009.

Sondakh. "Fungsi Local Investment Regulation Dalam Meningkatkan Keunggulan Daerah Pada Pertumbuhan Investasi." Jurnal IImu Hukum AMANNA GAPPA 21 (2013).

Sopandi, Andi \& Nazmulmunir, N. "Pengembangan Iklim Investasi Daerah." Kybernan 3, no. 1 (2012): 10-24.

Suparman, H. N., Rheza, B., Agustine, T. E., Prawira, M. Y., Febryanti, N. A., \& Jannah, A. N. Regulasi Usaha Di Daerah Kajian Perda Pungutan Dan Perizinan, 2017.

Thalhah, M. "Peraturan Daerah Bermasala." Jurnal Ilmu Sosial, 30(65) (2007): 231237.

Tim UJDIH BPK Perwakilan Provinsi Jawa Barat. "Mekanisme Pencabutan / PembatalanPeraturanDaerah,Peraturan Kepala Daerah, Dan Keputusan Kepala Daerah Yang Bermasalah Berdasarkan Peraturan Perundang-Undangan Di Indonesia," 2016.

Waldron, J., \& Wamron, J. "The Dignity of Legislation." L. Rev 633, no. 2 (1995).

Yani, M. "Penyusunan Naskah Akademik Sesuai Ketentuan Undang-Undang Nomor 12 Tahun 2011 Dalam Proses Pembentukan Peraturan Daerah." Jurnal Ilmu Hukum Maret, 5(1) (2014): 155172.
Yulianto, T. "Hukum Sebagai Sarana Untuk Melindungi Pekerja/Buruh Dalam Hubungan Industrial." Orbith 8 (2012): 104-108.

Zuhro, R. S \& Prasojo, E. Kisruh Peraturan Daerah: Mengurai Masalah Dan Solusinya. Yogyakarta: Ombak, 2010. 
JIKH Vol. 13 No. 2 Juli 2019: 229 - 244

\section{HALAMAN KOSONG}

